\title{
Reliability and safety, and the risk of construction damage in mining areas
}

\author{
Izabela Skrzypczak $^{1 *}$, Janusz P. Kogut ${ }^{2}$, Wanda Kokoszka ${ }^{1}$, and Grzegorz Oleniacz ${ }^{1}$ \\ ${ }^{1}$ Rzeszow University of Technology, Faculty of Civil, Environmental Engineering and Architecture, \\ Rzeszow, Poland \\ ${ }^{2}$ Cracow University of Technology, Faculty of Civil Engineering, Krakow, Poland
}

\begin{abstract}
This article concerns the reliability and safety of building structures in mining areas, with a particular emphasis on the quantitative risk analysis of buildings. The issues of threat assessment and risk estimation, in the design of facilities in mining exploitation areas, are presented here, indicating the difficulties and ambiguities associated with their quantification and quantitative analysis. This article presents the concept of quantitative risk assessment of the impact of mining exploitation, in accordance with ISO 13824 [1]. The risk analysis is illustrated through an example of a construction located within an area affected by mining exploitation.
\end{abstract}

Keywords: risk analysis, safety, damage, mining area

\section{Introduction}

Reliability, safety, and analysis of the risk of damage to building structures has at least two meanings in the literature: in general, qualitative and quantitative. General reliability is defined as the ability to perform the planned construction of a function at a certain time of use or as a specific condition of the structure. In particular, reliability is the probability that the designed structure does not exceed the limits specified in the planned operational time. Certain measures are taken to ensure the reliability of a structure. They include, in addition to relevant calculations, a range of activities related to ensuring durability and quality. These measures also aim to reduce calculation errors, as well as operational errors and the serviceability of structures [2]. Therefore, reliability is associated not only with the exceeding of conventional limit states, but also with the elimination and/or reduction of other hazards (e.g., in the case of construction works in mining areas with the limitation of the predicted impact of mining operations on the technical condition of buildings). While safety is narrower concept of reliability, it is usually associated with a lack of threat and often identified with the complement of the risk of human health, as well as with the economic, social, and environmental losses in the projected lifetime. In this narrower sense,

*Corresponding author: izas@prz.edu.pl 
safety is also referred to as the conditional reliability. Safety is defined as the probability that a structure, that meets the relevant requirements and conditions, will not reach certain arbitrary limit states during the assumed lifespan. The objects are designed for mining areas so that they are reliable and safe during their use, but they must be properly built and serviced. The exploitation of mining areas initiates a slow movement of rock masses and soil towards the excavation. The influence of exploitation on the surface of the site manifests itself in the form of uneven depressions, terrain deformations, and/or unfavorable changes in the level of the water table. Buildings are subject to various stress and strain conditions as a result of variable interactions. Due to terrain deformation, rigid (low deformation) structures will experience additional loads, while flexible (deformable) structures experience a more complex state of deformation. Therefore, construction objects in mining areas, in order to be reliable and safe to use, must be properly designed and constructed to predict the impact of mining operations. Knowledge of these problems concerns not only designers, but also contractors, supervisors, and those persons responsible for quality control and compliance tests in construction companies. Unfortunately, without an understanding of the assumptions and foundations of the theory of reliability, the application may lead to serious errors and misunderstandings in the design of building structures in mining areas. The detailed requirements regarding reliability are specified in the design standards of construction and in safety requirements in construction law, while the risk management requirements are formulated in quality and reliability standards.

\section{Reliability management}

In accordance with the standards for the design of building structures [3], the required reliability of building structures should be ensured by: designing and properly performing and undertaking quality assurance measures at every stage of construction project implementation. Various levels of reliability can be adopted to ensure ultimate and serviceability limit states of the structure. When choosing levels of reliability for a structure, it is recommended to take into account several relevant factors, including: possible causes of limit states, possible consequences of damage (such as life and health hazards), potential material losses, social reactions to existing damages, costs and procedures, and necessary procedures to be conducted in order to reduce the risk of damage.

The reliability of a structure can be determined by the classification structure as a whole or by the classification of its components. Reliability, relating to the bearing capacity and serviceability, can be achieved by the appropriate combination of: - preventive or protective measures; - calculation means (i.e. representative values of impacts and selection of partial coefficients); - actions and measures regarding quality assurance; - measures taken to reduce calculation, construction, and human errors; - measures concerning the following issues: basic requirements, degree of compactness, durability (including design lifetime), scope and quality of preliminary soil investigations and arrangements for possible impacts of mining operations, accuracy of accepted calculation models, construction details, proper implementation, adequate inspection, and maintenance in accordance with the procedures given in the project documentation.

Measures taken to prevent accidents and limit their consequences can be considered as interchangeable, to a narrow extent, provided that the required levels of reliability are maintained. Procedures and measures of the reliability management are formulated in order to enable the differentiation of the reliability of the structure and its elements (compare to Annex B [3]). 


\section{Strategies for designing buildings}

European norm [4] distinguished two basic strategies for structure design to work against the accidental actions in exceptional computational cases: a) strategies based on accidental actions and values established on the basis of statistical research or contractual values and based on design of the structure to bear accidental loading; structural design for sufficient minimum load-bearing; preventing or reducing the occurrence of accidental actions, b) strategies based on a limited range of local losses in the case when accidental impact is undefined or has a very large variation or frequency of occurrence is difficult to assess, consisted of: stiffening of structure; designing key elements for accidental impact of a normative value; compliance with standard conditions defined in the relevant codes, etc. As far as the design of buildings is concerned, due to the limitation of the allowable level of local destruction of undetermined reasons, there are four Consequence Classes defined depending on the type of building and its use, with the recommended number of strategies to ensure a satisfactory level of structural resistance in order to sustain localized failure without a disproportionate level of collapse: a) Class 1 - with no specific consideration necessary with regard to accidental actions, when a building is designed and constructed in accordance to the rules given in Eurocodes; b) Class 2a (Lower Risk Group) - as a complementary recommendation to Class 1 with providing of effective horizontal ties or effective anchorage of suspended floors to walls respectively from framed and load-bearing wall construction; c) Class $2 \mathrm{~b}$ (Upper Risk Group) - provided with effective horizontal ties for the framed and load-bearing wall construction, respectively, together with effective vertical ties in all supporting columns and walls, or to ensure that upon any casual removal of each supporting pillar and each beam supporting a column, or any nominal section of load-bearing wall (one at a time in each storey of the building) that the building remains stable and that any local damage does not exceed a given limit; d) Class 3 - systematic risk analysis of the building should be undertaken, taking into account both the normal hazards that may reasonably be foreseen and all abnormal hazards. Strategies recommended for the design of a building with Consequences Classes 1 and $2 \mathrm{a}$ are based on standard procedures and have already been applied in practice. In the case of buildings belonging to the Class $2 \mathrm{~b}$, verification against advanced numerical analysis is additionally required. In relation to the Class 3, dealing with buildings with frequently applied practical design (including buildings where a great many people have access), it is required to carry out systematic risk analysis that takes into account normal (predictable) and abnormal (unpredictable) hazards. However, the guidelines for the analysis and risk assessment offered by these standards, particularly the quantitative one, are rather general and their application, in practice, raises many doubts, requires specialized knowledge, is hard to reach, and often provides incomplete and inaccurate data. In order to achieve adequate structural stability and resistance disproportionate to cause and progressive destruction, it is recommended to use binding systems and wreaths, to diversify the directions of support of the horizontal floor slabs and to ensure that the conditions of the ties or membrane function after the destruction of their supports, and the partition of construction, etc. [2].

\section{Procedures of the building's risk assessment in mining areas}

The basis for assessing the risk of mining damage in building facilities is the forecast of the impact of the planned mining operation. The traffic plan should indicate the method used to calculate the deformation rates and should give the assumed values for parameters and coefficients. The assumptions for the forecast should include the results of surface deformation measurements [5]. It should be emphasized that neither the applicable legal provisions nor the method of its execution or the qualifications of contractors define the 
scope of the inventory of buildings. The GIG instruction [6], recommended for use in the Polish underground mining by the Commission for Surface Protection at the Higher Mining Office, distinguishes two procedures for assessing the resistance of buildings to permanent surface deformation. In the case of buildings with a masonry (longwall) load-bearing structure, from small-sized elements designed without taking into account the impact of mining operations, possibly protected during their use, it refers to the study [7]. As for those buildings with a different construction and buildings subject to special protection, it indicates the need to conduct an assessment. The potential damage of building's evaluation, as a result of mining subsidence, may be assessed by: the expected surface deformations, structural characteristics of construction, properties of building materials and static features of the building system, mechanical properties of the substrate, and current technical condition of the structure. The basic criteria determining the resistance of a building object to a mining subsidence is to check the bearing capacity and serviceability limit state. The method of assessing the safety of the structure results from the adopted method of assessing the resistance [8]. The resistance to the horizontal deformations $\varepsilon$ of the surface and the curvature $\mathrm{K}$ is usually assessed. These surface deformation factors determine the stress state in the structural members. Resistance of buildings is not a permanent feature and may change due to technical conditions and the influence of the mining subsidence $[9,10]$. The assessment of the resistance of buildings to a continuous surface deformation is based on the determination of the permissible values of $K$ and $\varepsilon$, while maintaining the safety of buildings, causing a slight nuisance of their use due to cracks of width $d$ and shear strains $\gamma_{k}$ [6]. The resilience of existing buildings to mining subsidence depends on their structural characteristics, static features of structure, soil characteristics, and current technical condition [11]. The resilience of buildings designed and constructed for mining impacts is the resistance resulting from the values of curvatures $K$ and horizontal strains $\varepsilon$ adopted in projects. This depends on the correctness of the constructional protection made, the current technical condition of the buildings, and the impact on the mining operations. The resilience of buildings to continuous deformation of the substrate may be assessed on the basis of a detailed analysis of their structure, approximate methods, and expert knowledge [8]. The approximate methods have been developed for buildings with a masonry bearing structure. The commonly used methods to assess the resistance of buildings include: a detailed method, based on the diagnosis of the technical condition of the structure, taking into account the predicted impacts of mining exploitation [8]; a point method [12,13]; a modified point method [14,15]; - a resistance scale method [16]; a parametric method [17]; - a safe estimation method [18]; - expert knowledge [11]. Currently, the modified point method (i.e., a version developed by GIG) is commonly used [14,15]. The modified point method, like other earlier versions of this method, consists of assigning an appropriate number of points for each of the seven distinct features of the building and its subgrade. The modified point method is being developed together with detailed instructions for its application, and it allows for the assessment of the resistance of both free-standing and multi-segment buildings. Kawulok [8] established the detailed rules for assessing the resistance of buildings to the impact of mining surface deformations. There are four groups of objects: buildings with a longitudinal load bearing structure, mainly residential and public buildings; other buildings with a rigid structural design, with different solutions of the support system (e.g., skeletal buildings); buildings of various uses, including residential and public buildings; industrial objects such as industrial halls, storage facilities, and other purpose objects which are not belonging to the groups formerly mentioned; engineering structures and structures of special design or other types, such as churches or worship objects, or those requiring special protection (e.g., historic buildings). The safe estimation method is associated with a preliminary assessment of the hazards of buildings influenced by the expected mining operation. This method gives more reliable results than the method 
of comparing building resistance categories with mining area categories [18,19]. The application of the safe estimation method requires determining, among others, the difference between limit resistance and critical resistance, and it creates certain difficulties $[18,19]$. For this reason, the division of buildings into safe and unsafe (according to safe estimation) and an assessment of the expected degree of damage should be supplemented by information on the probability of damage and risk to buildings subject to damage in mining areas [18].

\section{Risk analysis}

The mining exploitation in urban areas, as well as any other economic activity, is associated with risk and uncertainty. The risk may be defined as the product of probability and negative consequences of occurrence of adverse events. The threat is the possibility of an event causing the loss of life, health, and/or social, as well as physical and ecological losses. Hazard identification and identification of possible disaster scenarios or design failure and the assessment of their probability and the consequences that may result belong to the fundamental tasks related to risk analysis. The risk associated with the different stages of the construction process varies and depends on each stage of the threats. Due to the causes of accidents, two types of threats can be distinguished: natural and anthropogenic. Natural hazards are associated with the accidental nature of actions on buildings, as well as random properties of materials and the geometrical dimensions of the structural elements from which they are made. The threat of an anthropogenic, human factor is directly related to the construction process and results from unintended or deliberate derogate from the principles and rules of construction activities (errors and omissions made by human beings). In civil engineering, the risk is a measure of danger, defined as the combination of probability and consequences of the occurrence of an undesirable event. [20,21]. In the case of the random nature of events, they are treated as random events and the risk is a determinate or random value that can be calculated using the following formula:

$$
R=\sum_{i=1}^{n} P_{i} \cdot S_{i}
$$

where: $P_{i}$ - the probabil0ity of damage to a structure in the area of mining activity, $S_{i}-$ effects related to the damage of the structure in the area of mining activity. Thus, the objective risk in the design of structures in mining areas is related to the reliability of the structure.

\section{Risk quantification}

EN 1991-1-7: 2006 norm [4] provides two methods of risk analysis for buildings and structures: the qualitative risk as a part of risk analysis, which identifies all hazards and corresponding hazard scenarios. It requires a detailed examination and understanding of the system. It also requires that the use of buildings and its implications for safety of use is acceptable. For such a reason, a number of techniques of risk analysis have been developed to assist e.g., Process Hazard Analysis (or evaluation) - PHA, Hazard and Operability study - HAZOP [22], fault tree, event tree, decision tree, casual networks, etc. [23,24,25], the quantitative risk as a part of risk analysis probabilities estimated for all undesired events and their subsequent consequences, as it stands in ISO 13824 [1], it may be given by the following formula:

$$
R=\sum_{i=1}^{n_{H}} p\left(H_{i}\right) \sum_{j=1}^{n_{p}} \sum_{k=1}^{n_{s}} p\left(D_{j} \mid H_{i}\right) p\left(S_{k} \mid D_{j}\right) C\left(S_{k}\right)
$$


where, it is assumed that the structure is subjected to $n_{H}$ different hazards, that may cause damage to the structure in $n_{p}$ different ways, where the complex state of a damaged structure may be considered in $n_{s}$ unfavorable conditions of $S_{k}$ resulting in corresponding consequences $C\left(S_{k}\right), p\left(H_{i}\right)$ is the probability of the occurrence of the $i$-th hazard, $p\left(D_{j} \mid H_{i}\right)$ is the conditional probability of the $\mathrm{j}$-th state of causing structural damage to the $\mathrm{i}$-th given hazard, and $p\left(\mathrm{~S}_{k} \mid D_{j}\right)$ is the conditional probability of the $k$-th adverse overall structural performance $S_{k}$ given the $j$-th damage state. The quantitative analysis of risk calculated as the value of risk in monetary units according to formula (1) should be treated as nominal size, which has no direct reference to the financial outlay incurred in the event of structural damage. Considering that the maximum tolerable probability of structural damage $p_{f d}$ in the full life cycle cost is equal to $C(S)$, it qualifies for the relevant class of reliability $(R C X$ $=\{R C 3, R C 2, R C 1\})$. For the reference period of $T_{0}$, as defined in EN 1990: 2012. Basis of structural design as a measure of risk associated with the analysed exceptional situation, one may take a risk index $i_{R}$ :

$$
i_{R}=\frac{R}{R_{a c}} ; R_{a c}=p_{f d}\left(R C X ; T_{0}\right) \cdot C(S)
$$

Common quantitative risk analysis covers: an estimation of the probability of the possible risks for fixed intensity; an estimation of the probability of various failures and their consequences for the considered threats; an estimation of the probability of adverse reaction to local structural damage and the consequences related to it. The analysis of the causes of damages to structures indicates that they were scarcely associated with insufficient values of parameters adopted in the construction documentation, and their increase would not have prevented the damage [26]. Usually, the reasons for accidents are such factors or circumstances that are not contained in the design process and/or an evaluation of the technical conditions. Hence, a clear analysis and risk assessment is recommended as the most appropriate and promising method to ensure a satisfactory level of resistance to accidental loads and other impacts acting on the structure, including the impacts from mining operations.

\section{Risk assessment}

The key issue of controversy arousing in the risk assessment is to determine the risk acceptance criterion. There are numerous proposals for quality criteria and mixed criteria, which are usually not very precise, leading to substantially different results. Most often, these are different variants of the principle of ALARP (i.e., the risk as low as reasonably practicable). European norm [4] presented a mixed criterion as the mathematical expectation of the consequences of an undesired event - see Fig. 1.

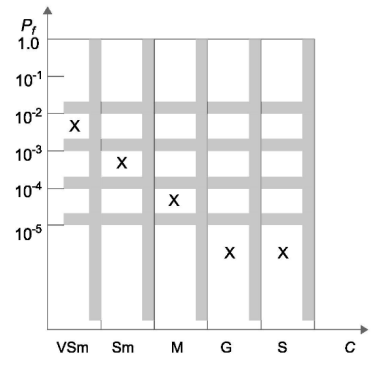

$\mathbf{X}$ - represents the largest acceptable level of risk; and C - Consequence: VSm -Very Small, Sm Small, $\mathbf{M}$ - Moderate, $\mathbf{G}$ - Great, $\mathbf{S}$ - Serious, and $\mathbf{P}_{\mathbf{f}}-$ Probability

Fig. 1. Consequences diagram [4]. 


\section{Risk analysis in mining area - case study}

The analysis is performed to a building classified to the consequence Class 3, with monolithic structure of reinforced concrete columns and slabs built in the mining area. Accidental action on the structure is caused by the occurrence of a hazardous landslide and is marked as $H_{l}$, (e.g. the threat of mining influences through the occurrence of horizontal deformations and sudden depression of the area), which occurs with probability of $p\left(H_{l}\right)=$ 0.01 , and may cause either the local damage to the building $D_{l}$ or destruction of the foundation $D_{2}$ with the conditional probability equal to: $p\left(D_{1} \mid H_{l}\right)=0.1$ and $p\left(D_{2} \mid H_{l}\right)=$ 0.01 . The probability $p\left(H_{l}\right)$ is determined by taking into account the specificities of the mining area (i.e. high inconvenience of using a building due to the influence of continuous surface deformation), hence the value of 0.01 . The effect of local defects in both structures, is defined as the damaged part of the structure $S_{1}$ (up to $100 \mathrm{~m}^{2}$ floor or the floor area of 15\% (EN 1991-1-7: 2006)) or destruction of larger parts or the entire structure $S_{2}$, where the conditional probabilities of occurrence are as follows: $p\left(S_{I} \mid D_{I}\right)=0.1 ; p\left(S_{2} \mid D_{1}\right)=0.01$; $p\left(S_{I} \mid D_{2}\right)=0.5 ; p\left(S_{2} \mid D_{2}\right)=0.05$. The consequences of partial damage to the building and the whole destruction are estimated, respectively: $C\left(S_{1}\right)=€ 750000$ and $C\left(S_{2}\right)=€ 15.000000$. On the basis of formula (1), the risk value is equal to $R=833.25$. An acceptable risk of damage to the structure is deemed to have a reliability class $R C 3$ for the reference period and is equal to $T_{0}=50$ years, and by taking into account the cost of investment in the full life cycle of $C(S)=€ 7.500000$, is equal to: $R_{a c}=8.5 \cdot 10^{-6} \cdot 7.5 \cdot 10^{6}=63.75$. The ratio of risk associated with the destruction of the structure, as a result of the present emergency situation and tolerable risk is: $i_{R}=R / R_{a c}=833.25 / 63.75=13.07$. This means that it exceeds the acceptable level of risk by more than 13 times. It is, therefore, necessary to take appropriate action to reduce it; for example, by applying a more effective procedure related to economic evaluation of continuous deformation effects on the building resistance, saving the building from the effects of mining exploitation through appropriate protection of the structure and its foundations, and taking into account the related costs of protection.

\section{Final remarks}

The assessment of damage to buildings in mining areas is an inherent part of spatial and financial management. Such an analysis is carried out for the planned project (e.g., the further exploitation of a given coal deck), which may endanger the safety of people and structures and the future investment in mining areas. The optimal criterion for designing, dimensioning, and assessing the condition of structures in mining areas allows for the inclusion of quantitative and qualitative requirements, and it is the criterion of minimum safety. The current recommendations for quantitative analysis of risk assessment are quite general and have raised a number of concerns. They are mostly due to the interpretation and quantification of the probability of occurrence of threats, their local and global effects, and the risk consequences. The risk assessment in structural design involves determining the class of structural reliability (acceptable likelihood of destruction), the number of potential casualties, and either the financial, social, ecological, or other consequences. It is particularly difficult to assess the impact of structural damage - the cost of loss. In the case of extractive operations, it is important to be aware of the relationship between loss costs and prevention costs [7]. The total cost of mining prevention, building prevention, and disposal is dependent on priorities. If surface protection is preferred, then construction investment and disposal expenditures may be higher than mining investment expenditures. In some cases, this may lead to the abandonment of mining. If intensive exploitation is preferred, the cost of mining protection rises. At the same time, the degree of nuisance of the influence of exploitation on surface development increases. It is then necessary to 
increase the cost of mining prevention, in relation to the costs of building prevention and the removal of the effects of mining exploitation, to allow for a greater deformation of the surface or a greater intensity of mining shocks. Often, the cost analysis does not take into account factors such as company image, public trust, and the influence of public opinion. These costs are not measurable, but they may affect business, credibility, business relationships, etc.

\section{References}

1. ISO 13824: 2009. Bases for design of structures - General principles on risk assessment of systems involving structures. (2009). International Organization for Standardization

2. Wolinski, Sz. (2006), Risk reliability-based design, in Proceedings of the $11^{\text {th }}$ International Conference on Metal Structures, London-Rzeszów: Taylor \& Francis, pp. 887-895

3. EN 1990: 2012. Basis of structural design

4. EN 1991-1-7: 2006. Accidental actions Part 1-7: General actions - Accidental actions

5. Wytyczne w zakresie minimalnych wymogów treści planów ruchu podziemnych zakładów górniczych w aspekcie ochrony powierzchni, Wyższy Urząd Górniczy, Katowice 2013

6. Instrukcja $\mathrm{nr} 12$, Zasady oceny możliwości prowadzenia podziemnej eksploatacji górniczej z uwagi na ochronę obiektów budowlanych, Wyd. GIG, Katowice 2000

7. Kwiatek J. (ed.), (1997) Ochrona obiektów budowlanych na terenach górniczych. Katowice, Wydawnictwo GIG

8. Kawulok M. (2007), Kryteria oceny odporności obiektów budowlanych na ciągłe wpływy eksploatacji górniczej. Prace Naukowe GIG: Górnictwo i Środowisko, V/2007

9. Kwiatek J. (2007), Obiekty budowlane na terenach górniczych, Katowice, Wyd. GIG

10. Kwiatek J. (2010), Ocena niezawodności budynków na terenach wstrząsów górniczych, Górnictwo i Geologia, z. 2, (t. 5), pp. 121-131

11. Mika W., Kaszowska O. (2015), Kryteria dopuszczania eksploatacji górniczej pod terenami zabudowanymi, Przegląd Górniczy, pp. 44-49

12. Przybyła H., Świądrowski W. (1968), Określenia odporności istniejących obiektów budownictwa powierzchniowego na wpływ eksploatacji górniczej, Ochrona Terenów Górniczych, No. 4

13. Lejczak W., Kiczan W., Lubas B., Stranz B., and Bojarski Z. (1969): Zasady stosowania budownictwa zastępczego na terenach górniczych. Wyd. „Śląsk”, Katowice

14. Gil-Kleczeńska B., Mika W., and Soczawa Ł. (1990): Zmodyfikowana metoda punktowa oceny odporności obiektów budowlanych zabudowy mieszkalnej na wpływy eksploatacji górniczej o charakterze ciągłym. Materiały V Konferencji „Budownictwo na Terenach Górniczych". Katowice-Kamień k. Rybnika

15. Mika W. (2006), Zmodyfikowana metoda punktowa oceny odporności budynków w świetle dotychczasowych badań i doświadczeń. Prace Naukowe GIG: Górnictwo i Środowisko

16. Kawulok M., Lipski Z. (1995), Podstawy statystycznej metody oceny odporności budynków na wpływy eksploatacji górniczej, Materiały KN-T, III Dni Miernictwa Górniczego i Ochrony Terenów Górniczych, Ustroń - Zawodzie, pp. 305-309

17. Fedorowicz J., Kawulok M. (1997), Odkształceniowe kryterium oceny odporności budynków na terenach górniczych, Prace Naukowe GIG, Seria Konferencje, Katowice, pp. 33-47 
18. Ostrowski J. (2006), Deformacje powierzchni a zagrożenie uszkodzeniami budynków na terenach górniczych w ujęciu probabilistycznym, Rozprawy monografie 160, Uczelniane Wydawnictwa Naukowo-Dydaktyczne, Kraków

19. Ostrowski J., Ćmiel A. (2008), The use of a logit model to predict the probability of damage to bullding structures in mining terrains, Archives of Mining Sciences, 53 (2), pp. 161-182

20. JCSS Probabilistic Model Code Part 3: Resistance Models, 10.10.2000

21. Pilecka E. (2007), Statistical analysis of the relation between locations of high energy epicenter tremors and lineaments in areas of the Upper Silesian Basin, Mineral Resources Management, 23 (4), 101-109

22. Steward, M., Melchers, R. (1997). Probabilistic risk assessment of engineering systems. London: Chapman Hall

23. Baker, J., Schubert, M., and Faber, M. (2008). On the assessment of robustness. Journal of Structural Safety, 30 (3), pp. 253-267

24. Faber, M. (ed.), (2008). Risk Assessment in Engineering Principles. System Representation and Risk Criteria. Zurich: Joint Committee on Structural Safety.

25. Knoll, F., Vogel, T. (2009). Design for robustness. Structural Engineering Documents, 11, pp. 253-267

26. Matousek, M. (1977). Outcomings of a Survey on 800 Construction Failures. In IABSE Colloquium on Inspection and Quality Control. ETH Zurich: Institute of Structural Engineering

27. Popiołek E. (1989), Ochrona terenów górniczych, Skrypt nr 1172, AGH Kraków 